\title{
Sulphur Concentration in Imported Coal Around the Tamabil Area, Sylhet, Bangladesh
}

\author{
Mahamudul Hashan ${ }^{1, *}$, M. Farhad Howladar ${ }^{2}$, Labiba Nusrat Jahan ${ }^{2}$ \\ ${ }^{1}$ Ecole Nationale Superieure De Geologie, University of Lorraine, Nancy, France \\ ${ }^{2}$ Department of Petroleum and Mining Engineering, Shahjalal University of Science and Technology, Sylhet, Bangladesh
}

\section{Email address:}

mahmud_pge_sust@yahoo.com (M. Hashan)

\section{To cite this article:}

Mahamudul Hashan, M. Farhad Howladar, Labiba Nusrat Jahan. Sulphur Concentration in Imported Coal Around the Tamabil Area, Sylhet, Bangladesh. International Journal of Environmental Monitoring and Analysis. Vol. 4, No. 1, 2016, pp. 27-30.

doi: $10.11648 /$ j.ijema.20160401.15

\begin{abstract}
Bangladesh imports large amount of Indian coal every year in order to partly fulfill the demand of solid fuel. This research presents the quality and concentration of sulphur in imported coal. To accomplish the goal, twelve coal samples were collected from imported coal deposits of Tamabil, Sylhet in different times. Results show that the sulphur content ranges from $1.42-5.3 \mathrm{wt} \%$ meaning that the imported coal is high sulphured low quality coal. The research also deals with the possibility of applying desulphurization techniques to trim down sulphur from this coal as this poor grade imported coal is not environment friendly and may cause severe health and environmental problems. It was found that, reducing sulphur content from such a high value to less than acceptable limit is very much expensive which might not be affordable for Bangladesh.
\end{abstract}

Keywords: Imported Coal, Sulphur Content, Desulphurization Technique, Desulphurization Cost

\section{Introduction}

Coal is s a variety of sedimentary, combustible, solid, organic rocks that are composed mainly of carbon and different amounts of other components which includes hydrogen, oxygen, sulphur and moisture. After the decomposition of organic materials that have been subjected to geologic heat and pressure over millions of years, coal is formed. As it cannot be replenished on a human time frame, coal is considered as non-renewable resource. Currently $40 \%$ of the world's electricity needs is provided by coal. After oil, it is the second source of primary energy, and the first source of electricity generation in the world [1]. Irrespective of its economic benefits for the countries, the environmental impact of coal use, especially that coming from carbon dioxide and sulphur dioxide emissions, should not be overlooked. However, the energy infrastructure of Bangladesh is changing from a gas based mono-energy to a multiple energy system in which coal is going to play a vital role. In the country for more than two decades there are significant coal deposits known to occur, but the development of the coal resources is too little and delayed [2]. In 2011 in Bangladesh, 2.5\% of the electricity generated was supplied by coal and almost $80 \%$ by gas. The country's overall coal production was around 3,000 tons a day in May
2011, from the only producing state-owned coal mine in Barapukuria, Dinajpur. To cope with the rapid increase in electricity demand and insufficiency of gas for power generation, the Bangladesh government is in search for both domestic and imported coal sources to satisfy a momentous portion of its ambitious power generation expansion plans. The Bangladesh Power Development Board flagged that the government wanted an additional 12,000 MW in capacity installed by the end of 2016, 24,000 MW by 2021 and 39,000 MW by 2030 in its annual report (2010-2011) [3]. To meet these demands, the country imports 0.8 to 0.85 million tons of coal through Sylhet border from India every year $[4,5]$. These imported coals (see Figure 1) contain high sulphur. Because of environmental and health issues along with other countries Bangladesh also demands for coal with low sulphur. With the burn of high-sulphured coal, sulphur dioxide is emitted which causes several health and environmental problems.

In this research the prime focus is to determine the concentration level of sulphur content and the quality of the imported coal; secondly, to compare the obtained data with the quantity of sulphur in coal of major coal producing countries in the world; thirdly, possibility of applying desulphurization techniques to reduce the sulphur content from imported coal and lastly, the necessary recommendation 
from authors view point.
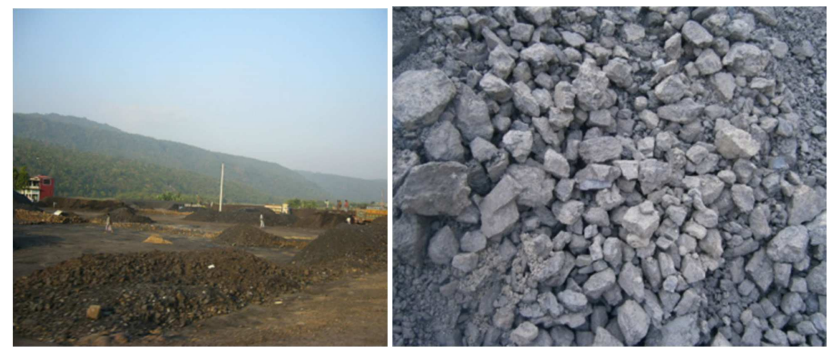

Fig. 1. Imported coal deposits in Tamabil, Sylhet, Bangladesh.

\section{Materials and Methods}

Bomb calorimeter was used to determine the sulphur content of the coal samples collected from imported coal deposits of Tamabil, Sylhet. To perform the analysis successfully, firstly the collected coal samples were crushed by crusher and then they were pulverized with the assist of pulverizer. After that, the weighed sample of powdered coal was burnt completely in Bomb calorimeter in a current of oxygen. Ash obtained in bomb calorimeter was extracted with dilute hydrochloric acid and later was treated with barium chloride solution. The precipated barium sulphate $\left(\mathrm{BaSO}_{4}\right)$ was filtered, dried and weighed. Sulphur concentration of the collected coal samples was calculated based on the fact that, 32 grams of sulphur in the sample give 1 gram molecule of barium sulphate $\left(\mathrm{BaSO}_{4}\right)$.

\section{Results and Discussion}

\subsection{Analyzed Sulphur in Imported Coal}

Twelve coal samples were collected in different times from imported coal deposits in Tamabil, Sylhet to know the intensity of sulphur content as well as the quality of the imported coal from India. Analyzed concentrations of sulphur in the sample $1,2,3,4,5,6,7,8,9,10,11$ and 12 were $5.3,2.5,3.9,3.28,3.31,3.1,1.42,4.68,3.54,3.71,4.19$ and $3.83 \mathrm{wt} \%$ respectively (see Table 1 ). The average sulphur content of these samples was 3.56 which is quite high. Collected coal samples were graded according to coal grading system proposed by [6] (see Table 1) i.e. coals were graded based on the sulphur content such as low sulphur coal ( $0-1 \%$ sulphur), medium sulphur coal ( $1-3 \%$ sulphur) and high sulphur coal (more than $3 \%$ coal).

The sulphur compound present in the coal gives off a major pollutant sulphur dioxide that pollutes the environment by creating bad smoke and acid rain $[2,6]$. As a result, sulphur reduces the value of coal. On carbonization sulphur is expelled as $\mathrm{H}_{2} \mathrm{~S}, \mathrm{CS}_{2}$ and thiophene which are dangerous for atmosphere [7]. Moreover, sulphur affects clinkering and slugging tendencies, corrodes chimney and other equipments such as air heaters and economizers, and limits exit flue gas temperature [8]. Thus from this discussion it is unambiguous that imported high sulphured low quality coal is destructive for our present and future environment.

Table 1. Concentration of sulphur in imported coal samples.

\begin{tabular}{llllll}
\hline No. of sample & $\begin{array}{l}\text { Concentration of } \\
\text { Sulphur }(\mathbf{W t} \%)\end{array}$ & $\begin{array}{l}\text { Grade of Coal based on } \\
\text { Sulphur concentration }\end{array}$ & No. of sample & $\begin{array}{l}\text { Concentration of } \\
\text { Sulphur (Wt \%) }\end{array}$ & $\begin{array}{l}\text { Grade of Coal based on } \\
\text { Sulphur concentration }\end{array}$ \\
\hline 1 & 5.30 & High sulphur coal & 7 & 1.42 & High sulphur coal \\
2 & 2.50 & High sulphur coal & 8 & 4.68 & High sulphur coal \\
3 & 3.90 & High sulphur coal & 9 & 3.54 & High sulphur coal \\
4 & 3.28 & High sulphur coal & 10 & 3.71 & High sulphur coal \\
5 & 3.31 & High sulphur coal & 11 & 4.19 & High sulphur coal \\
6 & 3.10 & High sulphur coal & 12 & 3.83 & High sulphur coal \\
\hline
\end{tabular}

\subsection{Comparison Between the Sulphur Concentrations of Imported Coal with the Major Coal Producing Countries}

The characterization of coal quality is an important aspect of the assessment of future utilization of coal. Sulphur content is one of the most significant parameters to assess the coal quality. Its presence is always undesirable for whatever purpose coal is burnt as the existence of high sulphur degrades the quality of coal and pollutes the environment [9].

Comparison between the sulphur concentrations of imported coal with the major coal producing countries has been made in Figure 2 which show that the imported coal is extremely high in sulphur content with respect to other major coal producing countries. Calculated average sulphur content is $3.56(\mathrm{Wt} \%)$ which is even three to five times higher than other major coal producing countries.

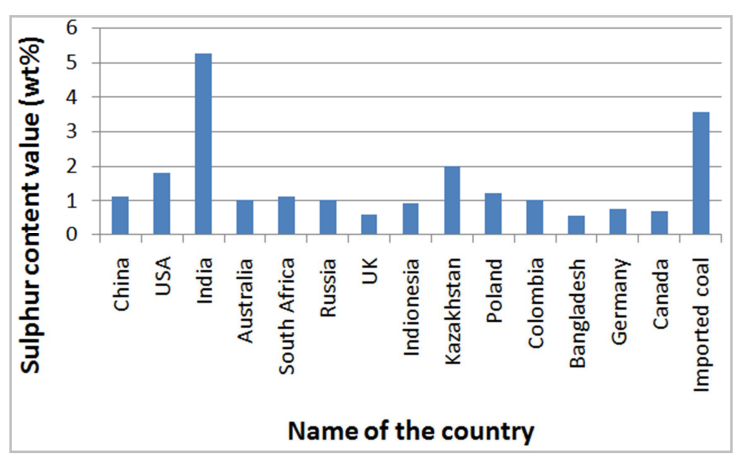

Fig. 2. Comparison of sulphur contents of major coal producing countries in the world $[7,18]$. 


\subsection{Techniques to Reduce Sulphur from Imported Coal}

To reduce sulphur from coal, currently desulphurization techniques are widely used though the application of such techniques are extremely expensive. Desulphurization techniques are classified as physical, chemical, thermal and biological (see Figure 3) which are broadly applied for coal desulphurization prior to combustion [7]. Most of the research works on coal desulphurization have been focused on pyritic sulphur removal, which represents at least half of the total sulphur content in coal. Organic sulphur is more difficult to remove by conventional processes since it is firmly bonded to organic units [10].

Most effective physical desulphurization techniques are coal pre-cleaning (advanced flotation), air spared hydrocyclone (froth flotation) and spherical agglomeration [7]. These techniques are effective to remove about 81.8, 86 and $80 \%$ of pyritic sulphur, respectively [11]. In addition, physical treatment also includes magnetic separation or the use of hydro-cyclones which principally removes inorganic sulphur [12], whereas the elimination of organic sulphur entails the chemical and/or microbial treatment [13]. Chemical treatment involves the use of strong acids, bases or salts which normally applied at elevated temperatures, ranging between $200-300^{\circ} \mathrm{C}$ [7]. $\mathrm{HNO}_{3}$ leaching at atmospheric pressure and elevated temperature (up to $90^{\circ} \mathrm{C}$ ) seems extremely efficient achieving almost complete sulphur removal. Leaching with sodium carbonate, sodium hydroxide or potassium hydroxide is also effective, achieving about $90 \%$ removal of both inorganic and organic sulphur [14]. Thermal treatment techniques involve mainly pyrolysis or the use of air steam mixtures [15]. Both pyrolysis and the use of air steam mixtures operate at high temperature $\left(350-500^{\circ} \mathrm{C}\right)$ where the degree of desulphurization depends on number of parameters such as temperature, particle size, air-steam ratio/gas composition, coal rank, heating rate and type of reactor used [10]. Biological desulphurization is a well established laboratory technique that uses bacterial cultures (thermophilic or mesophilic bacteria) to oxidize pyrite and therefore to remove the sulphur from coal [16].

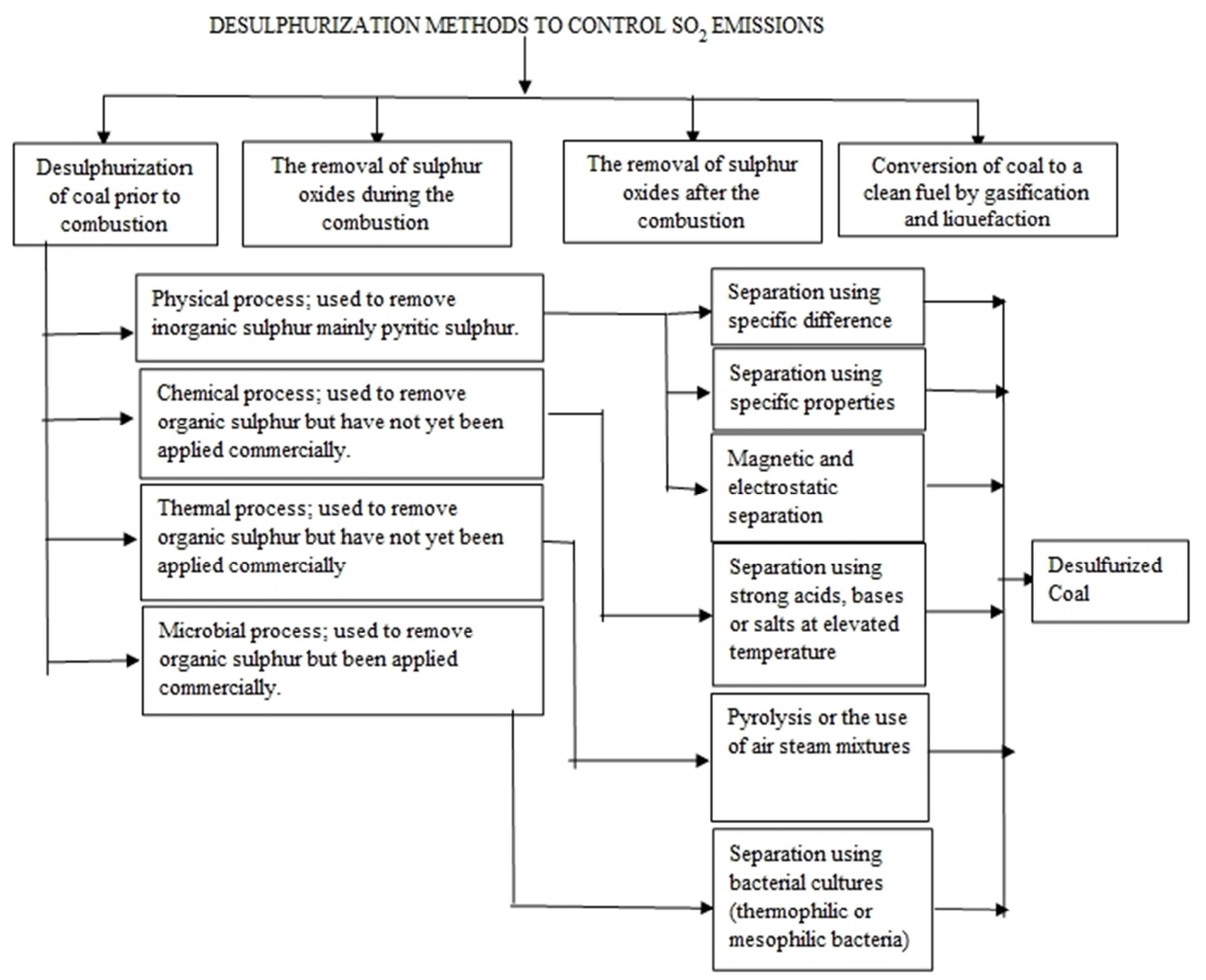

Fig. 3. Desulphurization methods to reduce sulphur from coal. 
Table 2. Approximate cost per year on desulphurization of imported coal.

\begin{tabular}{|c|c|c|c|c|c|c|}
\hline$[17]$ & & [11] & & & & \\
\hline $\begin{array}{l}\text { Approximate coal } \\
\text { import per year }\end{array}$ & $\begin{array}{l}\text { Approximate coal } \\
\text { import from India } \\
\text { per year }\end{array}$ & $\begin{array}{l}\text { Effective } \\
\text { desulphurization } \\
\text { techniques } \\
\end{array}$ & $\begin{array}{l}\text { Cost per } \\
\text { ton (USD) }\end{array}$ & $\begin{array}{l}\text { Sulphur } \\
\text { Reduction (\%) }\end{array}$ & $\begin{array}{l}\text { Cost required } \\
\text { for Indian coal } \\
\text { per year (USD) } \\
\end{array}$ & $\begin{array}{l}\text { Approximate total } \\
\text { cost per year (USD) }\end{array}$ \\
\hline \multirow{3}{*}{ 1-1.05 million tons } & \multirow{3}{*}{$0.8-0.85$ million tons } & Coal pre-cleaning & 27 & $81.8 \%$ & \multirow{3}{*}{$\begin{array}{l}21600000- \\
22950000 \\
21600000- \\
22950000 \\
18700000- \\
21250000\end{array}$} & $27000000-28350000$ \\
\hline & & Air spared Hydro-cyclone & 27 & $86 \%$ & & $27000000-28350000$ \\
\hline & & Spherical agglomeration & $22-25$ & $80 \%$ & & $2310000-26250000$ \\
\hline
\end{tabular}

\subsection{Cost to Reduce Sulphur from Imported Coal}

Cost associated with the most effective physical desulphurization techniques named coal pre-cleaning (advanced flotation), air spared hydro-cyclone (froth flotation) and spherical agglomeration are USD \$27/ton, USD \$27/ton and USD \$ 22-25/ton, respectively [7, 11]. Bangladesh imports approximately 1-1.05 million tons of coal every year [17]. If Bangladesh goes to desulphurize the imported coal while using above mentioned physical desulphurization techniques then it will take approximately USD 2700000028350000 every year (see Table 2 ) which is quite expensive.

\section{Conclusion}

The amount of Sulphur in the imported coal ranges from $1.42-5.3 \mathrm{Wt} \%$ which is quite high. The results lead to the fact that the imported coal belongs to high sulphured low quality coal which can cause harm to the human health, environment and coal powered industry. In order to reduce damages, the imported coal must be desulphurized or cleaned before using it which is very expensive. Thus the research brings some points into light which seeks to be emphasized. Firstly, uses of imported coal should get more attention along with coal cleaning technology. Secondly, Bangladesh has high grade local coal, which should be brought under production with full capacity. Finally necessary steps should be taken to use the unexcavated coal fields. In a nutshell it can be said that the dependency on imported coal should be reduced and the production of high quality local coal should be increased otherwise Bangladesh is going to face a drastic environmental hazard in near future.

\section{References}

[1] International Energy Agency. Available on: http://www.iea.org/topics/coal/. Accessed on: 08-04-2014.

[2] Imam, B. (2005). Energy Resources of Bangladesh, University grants commission of Bangladesh, Dhaka.

[3] Bangladesh and Coal. Available on: http://www.sourcewatch.org/index.php/Bangladesh_and_coal \#cite_note-2. Accessed on: 10-05-2012.
[4] National Policy Review Forum of Bangladesh, 2003.

[5] Energy and Power Development Forum, Bangladesh, 2010.

[6] Ward, C. R. (1984). Coal geology and Coal Technology. Blackwell Scientific Publication, Oxford, 345p.

[7] Ohtsuka, H. (2009). Desulferization of Coal. Journal of Coal, oil, Shale, Natural Bitumen, Heavy oil and Peat, vol. 1, pp. 1-5.

[8] Properties of coal and coal classification. Available on: http://www.scribd.com/doc/58494434/Property-of-Coal. Accessed on: 29-03-2012.

[9] Qiu, Y., Mao, S., Zhang, Q., Tian, Y., Liu, Z. (2011). Preliminary study on washability and composition analysis of highsulphur coal in some mining areas in Guizhou. Journal of Coal Science \& Engineering, vol. 17 (1), pp. 93-95.

[10] Barooah, P. K., Baruah, M. K. (1996). Sulphur in Assam coal. Journal of Fuel Processing Technology, vol. 46, pp. 83-97.

[11] Coal Desulphurization Techniques: Their Drawbacks and Costs. Available on: http://www.authorstream.com/Presentation/Misree-29715COAL-DESULPHURIZATIONTECHNIQUESDRAWBACKS-COSTS-SULPHUR-TYPES-asEntertainment-ppt-powerpoint/. Accessed on: 30-03-2012.

[12] Attia, Y. A. (ed.). (1985). Processing and utilization of high sulphur coals (Coal Science and Technology, 9), Elsevier, Amsterdam.

[13] Palmer, S., Hippo, E., Dorai, X. (1995). Selective oxidation pretreatments for the enhanced desulphurization of coal. Fuel, vol. 74 (2), pp. 193-200.

[14] Lolja, S. A (1999), A model for alkaline removal of sulphur from a low rank coal, Fuel Processing Technology, Vol. 60, P. 185-194.

[15] Lin, L., Khang, S. J. and Keener, T. C. (1997), Coal desulphurization by mild pyrolysis in adual-auger coal feeder, Fuel Processing Technology, Vol. 53, P. 15-29.

[16] Gomez F., Amils R. and Marin I., (1997). Microbial ecology studies for the desulphurization of Spanish coals, Fuel Processing Technology, Vol. 52, P. 183-189.

[17] http://www.bdnews24.com. Accessed on: 12-08-2012.

[18] www.google.com. 